\title{
Content of phenolic compounds in soils originating from two long-term fertilization experiments
}

\author{
Wiera Sądej*, Andrzej Cezary Żołnowski, Olga Marczuk \\ University of Warmia and Mazury in Olsztyn, Poland \\ *Corresponding author's e-mail: wersad@uwm.edu.pl
}

\begin{abstract}
Keywords: Phenolic compounds, soil, long-term experiments, fertilization, FYM, slurry.
Abstract: The objective of the study was to compare the impact of three systems of multiannual fertilization applied in two long-term field experiments on the content of phenolic compounds in the soil. In the study, both natural (manure, slurry) and mineral (NPK) fertilizers were used, along with combined, organic-and-mineral fertilization. Experiment I was established in 1972 on grey brown podzolic soil; experiment II, in 1973 on brown soil. In both experiments crops were cultivated in a 7-year rotation, with a $75 \%$ share of cereals. The experimental samples were taken from the top layer of soil after 36 (experiment I) and 35 (experiment II) years following the establishment of the experiments. It was demonstrated that the presence of phenolic compounds in the soils was significantly dependent on the contents of organic $\mathrm{C}$ and total $\mathrm{N}$, type of soil and the type and dose of used fertilizers. In grey brown podzolic soil, the content of total phenolic compounds was at a lower level than the content found in brown soil. Multiannual fertilization contributed to an increase in the content of total phenolic compounds in relation to the values obtained in control objects, which was particularly reflected in the soil originating from objects fertilized with slurry applied at a dose being equivalent to manure in terms of the amount of introduced organic carbon. The percentage of water-soluble phenols in the total content of these compounds in grey brown podzolic soil was at the level of $18.4 \%$, while in brown soil it amounted to $29.1 \%$.
\end{abstract}

\section{Introduction}

Phenolic compounds are widespread in the environment. They are formed naturally during the decomposition of various substances of plant and animal origin, mainly polymers containing aromatic rings. Phenolic acids, such as caffeic, ferulic, $p$-coumaric, $o$-coumaric, $p$-hydroxybenzoic, syringic, and vanillic acid, are commonly found both in plant tissues and in the soil in which the plants are cultivated. They are also included in the composition of plant root exudates, and are components of flower and fruit dyes (Krupa and Latocha 2007). The main sources of these compounds are industry and agricultural activity (Wise and Kuske 2000, Thakur et al. 2013, Wang et al. 2015).

Phenolic compounds play an important role in the formation of relationships between the soil and vegetation. Through their accumulation in the rhizosphere they modify growth and development processes (Reigosa and Pedrol 2002): inter alia they inhibit cell division and cell elongation, force changes in cell ultrastructure ( $\mathrm{Li}$ et al. 2010), have a disintegrating effect on the structure and functioning of cytoplasmic membranes, block the activity of enzymes, and have an adverse effect on the uptake of water by plants, as well as the uptake of phosphorus, potassium and nitrogen ions by the roots. Some of them cause disturbances in the processes of photosynthesis and transpiration in plants (Wójcik-Wojtkowiak et al. 1998). Several of these compounds are substances with allelopathic activity, which is reflected in the toxicity exhibited even at low concentrations. Through the autotoxic activity, allelopathins restrict both the growth and development of plants and seed germination processes, which is particularly visible within the same group of species. The allelopathic impact of plant root exudates results in the "favouritism" of representatives of certain species, and the exclusion of the species currently inhabiting a particular ecosystem (Mazzoleni et al. 2007). The effects of the autotoxic impact of phenolic compounds have been demonstrated for many plant species, such as maize (Zea mays L.) (Ahmad and Bano 2013), barley (Hordeum vulgare L.) (Bouhaouel et al. 2015), wheat (Triticum aestivum L.) (Wu et al. 2008), and alfalfa (Medicago sativa L.) (Sołtys et al. 2010). Even small amounts of allelochemical substances may have a significant effect on the structure and functioning of a plant community (Djurdjević et al. 2004, 2012). It is generally believed that phenolic compounds are among the main factors of soil exhaustion, leading to a reduction in the yielding of crops. This particularly refers to the monocultural cultivation of crops.

It is difficult to obtain evidence indicating the occurrence of chemical interactions between plants under field conditions, as the compounds excreted by them may undergo numerous transformations in the soil (Bertin et al. 2003). Phenolic compounds present in the soil determine both the rate of decomposition of post-harvest residues and the release of 
nutrients therefrom. In monocultural crop cultivation the accumulation of soil humus may be slowed down due to the impact of phenolic antimicrobial substances, which include, inter alia, tannins and polyphenols (Wardle et al. 2003, Bonanomi et al. 2010). Both the quantitative and qualitative compositions of phenolic compounds in the soil are, to a large extent, dependent on the vegetation and soil (Mala et al. 2013, Natywa et al. 2014). Gartner and Cardon (2004) demonstrated that soils with a varied type of cultivated crops are characterised by a higher rate of decomposition of crop residues as compared with monocultural cultivation. Multiannual cultivation of crops with a great allelopathic potential may result in the accumulation of relatively high contents of phenolic compounds in the soil, which restrict the activity of microorganisms.

Having analysed the literature data, it may be concluded that the previous studies on the content of phenolic compounds primarily concerned the impact of cultivation systems (in particular monoculture) (Hruszka 1982a, 1982b, Furczak et al. 2001, Bertholdsson 2004, Sołtys et al. 2010, Ahmad and Bano 2013). Little attention was paid to the development of the content of these compounds under the influence of longterm and one-sided fertilization. The use of natural and organic fertilizers in various cultivation systems is commonly applied in order to improve the soils' richness in nutrients. This is also a method allowing for the management of large amounts of biodegradable organic wastes. Their positive impact on the soil and soil solution is well documented (Hayness and Naidu 1998, Aoyama and Kumakura 2001, Chantigny et al. 2001, Fangueiro et al. 2014, Szwed and Bohacz 2014). However, cases of contamination of surface waters and groundwater with nutrients (Sądej and Przekwas 2006a, 2006b) and microorganisms (Epstein et al. 1976) originating from these fertilizers have also been noted. Natural fertilizers are also a source of metabolites of plant origin, along with both the soluble (phenolic acids) and insoluble (lignins) phenolic compounds, which are very stable, and only become partially degraded in the digestive systems of animals (Jung et al. 1983). Even though some of these substances have an adverse effect on soil fertility (Northrup et al. 1999) and animal health (Hanya et al. 1976), their fate is very rarely studied, and not fully explained (Riffaldi et al. 1988, Paul et al. 1993). In view of the above, the objective of the study was defined, namely to compare the impact of three systems of multiannual fertilization applied in two field experiments with the proportion of cereals at a level of $75 \%$ in the crop rotation on the development of the content of total phenolic compounds and their water soluble fractions in the soil.

\section{Material and methods}

\section{Sites and experimental set-up}

The experimental material was soil originating from two multiannual field experiments. Experiment I was established in 1972 in Bałcyny near Ostróda (53³5’37'N. 1950'53”E); experiment II, in 1973, in Tomaszkowo near Olsztyn $\left(53^{\circ} 42^{\prime} 35^{\prime \prime} \mathrm{N}\right.$. $\left.20^{\circ} 26^{\prime} 01^{\prime \prime} \mathrm{E}\right)$. Both experiments were established using a randomised block design in six replications, in accordance with the diagram shown in Table 1.

Table 1. Design of experiment

\begin{tabular}{|c|l|}
\hline Objects & Fertilization \\
\hline 1 & Without fertilization \\
\hline 2 & Slurry dose I (equivalent to the rate of manure in terms of the amount of total nitrogen introduced into the soil) \\
\hline 3 & Slurry dose I + PK \\
\hline 4 & Slurry dose II (equivalent to the rate of manure in terms of the amount of organic carbon introduced into the soil) \\
\hline 5 & Slurry dose II \\
\hline 6 & FYM \\
\hline 7 & FYM + PK \\
\hline 8 & NPK \\
\hline
\end{tabular}

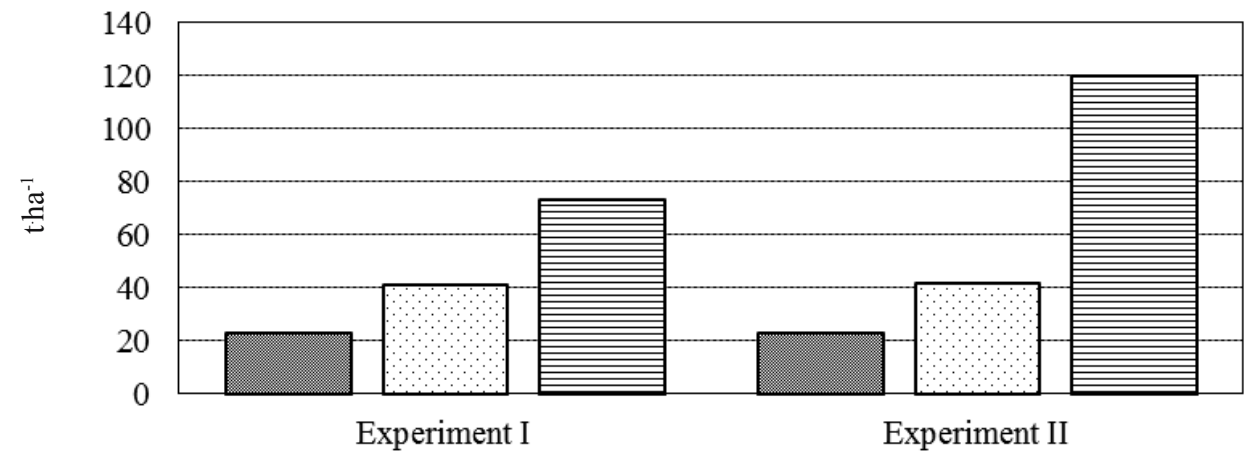

Experiment I

Experiment II

$\square$ FYM $\quad$ QSlurry dose I $\quad$ GSlurry dose II

Fig. 1. Doses of organic fertilizer applied in the experiments (average per year) 
Experiment I was carried out on grey brown podzolic soil formed from slightly loamy sand lying on light clay. According to the Polish agricultural classification, this soil was included in the good wheat complex, class III b, while according to the WRB classification, this is a soil of the Luvisols type, sub-type Albic Luvisols (IUSS Working Group WRB 2014). Experiment II was carried out on brown soil formed from slightly loamy sand. This soil was included in the good rye complex, class IV $\mathrm{b}$, and according to the WRB (IUSS Working Group WRB 2014), it was included in Cambisols, sub-type Brown Soils. The area of the experimental plots was $40 \mathrm{~m}^{2}$. In both experiments three fertilization systems were compared: organic (manure, slurry), mineral (NPK), and organic-and-mineral (Table 1). In experiment I the natural fertilizers applied originated from the bedding (manure) and non-bedding (slurry) cattle raising systems; in experiment II from swine raising. In each year slurry was applied in two doses: I - being equivalent to manure in terms of the amount of total nitrogen introduced into the soil, and II being equivalent to manure in terms of the amount of organic carbon introduced into the soil. In order to compare the effects of slurry and manure the experiments also included a series solely fertilized with mineral fertilizers (NPK), where nitrogen was introduced in a form of either ammonium nitrate $\mathrm{NH}_{4} \mathrm{NO}_{3}$ $(34 \% \mathrm{~N})$ or urea $\mathrm{CO}\left(\mathrm{NH}_{2}\right)_{2}(46 \% \mathrm{~N})$, phosphorus in the form of triple superphosphate (TSP) $\mathrm{Ca}\left(\mathrm{H}_{2} \mathrm{PO}_{4}\right)_{2} \cdot \mathrm{H}_{2} \mathrm{O}$ with the content of $\mathrm{P}$ at $20 \%$, and potassium in the form of a potassium soil $\mathrm{KCl}$ with a content of $\mathrm{K}$ at $50 \%$. Phosphorus and potassium, in the objects with organic-and-mineral fertilization, were applied at the amount equivalent to $1 / 2$ of the dose of those components being introduced into the objects with mineral fertilization only. The fertilizers were applied in the spring, prior to sowing spring cereals or planting root crops, and in the autumn, prior to sowing rape and winter cereals, whereas the dose of nitrogen in mineral fertilizers was divided into 3 parts, and $1 / 3$ doses were applied prior to sowing and $2 / 3$ for top dressing, on two dates.

In both experiments crops were cultivated in the following crop rotation: potato, spring barley + underplant crop of red clover with grasses, red clover with grasses, winter rape, winter wheat, winter rye (aftercrop), maize, spring barley, and winter wheat. In experiment I the underplant crop of clover with grasses was only cultivated in the first and second cycles of crop rotation, while in experiment II, only in the first cycle of crop rotation. Agricultural practices for particular species were performed on dates being optimal for the crops, in accordance with the principles of the proper technique for crop production. In this study soil samples taken after 36 (experiment I) and 35 (experiment II) years of the performance of the experiments were used for testing. The average chemical composition of natural fertilizers for the analysed study period is presented in Table 2, the average annual doses thereof are presented in Fig. 2, while the amount of nutrients introduced into the soil with organic and mineral fertilizers is shown in Fig. 2. Selected chemical and physical properties of the soils are provided in Table 3.

Table 2. Chemical composition of organic fertilizers, \% fresh matter

\begin{tabular}{|c|c|c|c|c|}
\hline \multirow{2}{*}{ Component } & \multicolumn{2}{|c|}{ Experiment I } & \multicolumn{2}{c|}{ Experiment II } \\
\cline { 2 - 5 } & FYM & Cattle slurry & FYM & Pig slurry \\
\hline DM & 23.53 & 8.20 & 26.11 & 5.11 \\
\hline $\mathrm{N}_{\text {tot }}$ & 0.49 & 0.31 & 0.58 & 0.37 \\
\hline $\mathrm{P}$ & 0.17 & 0.12 & 0.20 & 0.15 \\
\hline $\mathrm{K}$ & 0.41 & 0.31 & 0.45 & 0.18 \\
\hline $\mathrm{Ca}$ & 0.09 & 0.05 & 0.09 & 0.04 \\
\hline TOC & 0.12 & 0.10 & 0.17 & 0.07 \\
\hline TOC $_{\text {tot }}$ & 8.67 & 3.12 & 8.86 & 1.94 \\
\hline
\end{tabular}

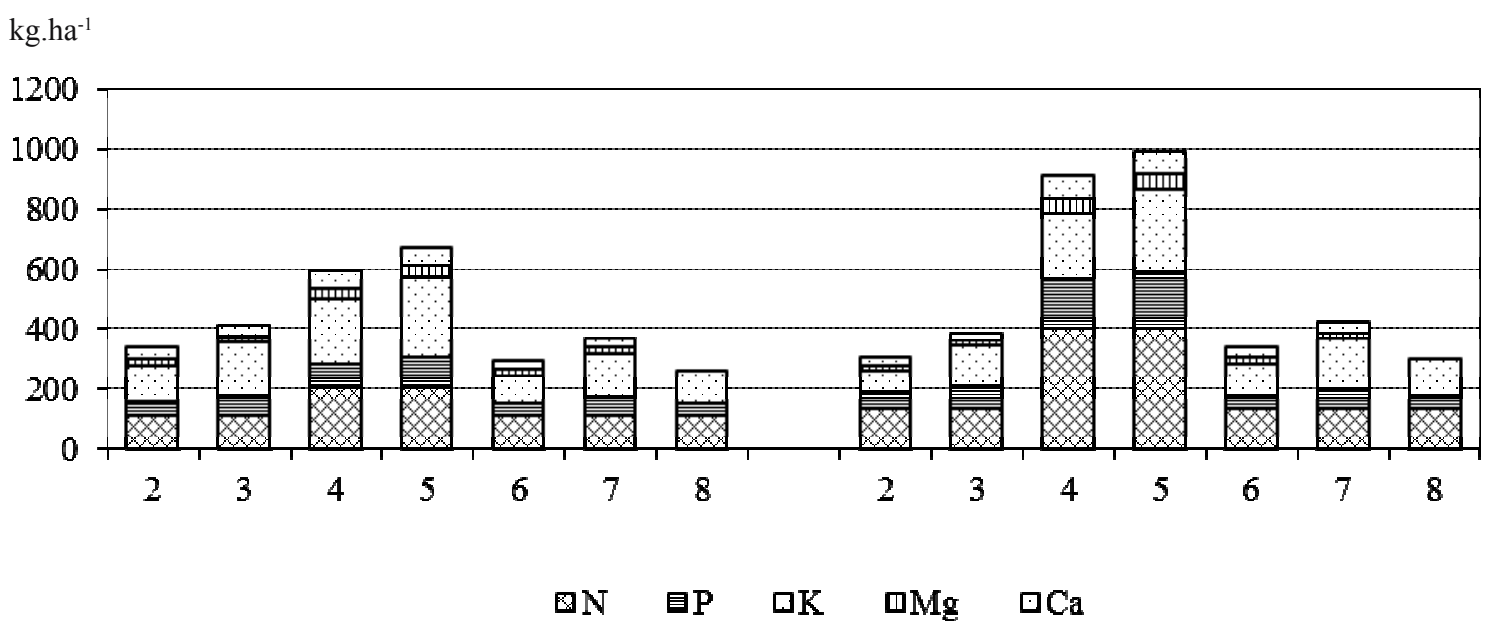

Fig. 2. The quantities of nutrients introduced to the soil with organic and mineral fertilizers (yearly means) 


\section{Soil sampling and chemical analyses}

The experimental material consisted of soil samples taken from the top layer $(0-25 \mathrm{~cm})$ using a $\varnothing 50 \mathrm{~mm}$ soil auger following the harvest of spring barley. After being dried at room temperature the soil was passed through a sieve with a $0.25 \mathrm{~mm}$ mesh, and stored in airtight polyethylene containers. In thus prepared samples the following were determined: the $\mathrm{pH}$ in $1 \mathrm{~mol} \mathrm{dm}^{-3}$ $\mathrm{KCl}$, the content of organic carbon (TOC), total nitrogen $\left(\mathrm{N}_{\text {tot }}\right)$, hydrolytical acidity (Hh), sum of basic cations (S), the content of total phenolic compounds (TPC), and the content of watersoluble phenolic compounds (WSPC). The determinations were performed in 3 parallel replications for each soil sample representing particular experimental objects.

Total phenolic compounds (TPC) were isolated from the soil using a mixture of ethyl alcohol $-\mathrm{C}_{2} \mathrm{H}_{5} \mathrm{OH}$ (POCh Gliwice) $(96 \% \mathrm{v} / \mathrm{v})+$ redistilled $\mathrm{H}_{2} \mathrm{O}+$ acetic acid $-\mathrm{CH}_{3} \mathrm{COOH}$ (SigmaAldrich $\left.^{\circledR}\right)$ in a ratio of 70:28:2 (v/v/v). The extraction was carried out at a soil-to-extraction mixture ratio of 1:10 (w/v). The samples were placed in polyethylene bottles and shaken on a rotary shaker (PAN Lublin, Poland) for 1 hour at a speed of $40 \mathrm{rpm}$, and then filtered through a cellulose filter type 389 (POCh Gliwice). The extracted phenolic compounds were determined using the spectrophotometric method, performing the absorbance measurements at a wavelength $\lambda=730 \mathrm{~nm}$ in relation to catechine solution as a standard (Hruszka 1982a, 1982b)

Water soluble phenolic compounds (WSPC) were also determined by the colorimetric method, in aqueous extracts $(1: 10 \mathrm{w} / \mathrm{v})$, using Folin-Ciocalteu reagent (Sigma-Aldrich $\left.{ }^{\circledR}\right)$, and performing the absorbance measurement at a wavelength of $\lambda=750 \mathrm{~nm}$ in relation to catechine solution as a standard (Lowe 1993).

Organic carbon (TOC) was determined using an oxidation-reduction method in a mixture of $0.066 \mathrm{M} \mathrm{dm}^{-3} \mathrm{~K}_{2} \mathrm{Cr}_{2} \mathrm{O}_{7}$ and $9 \mathrm{M} \mathrm{dm}^{-3} \mathrm{H}_{2} \mathrm{SO}_{4}$ (Tiessen and Moir 1993). The content of total nitrogen $\left(\mathrm{N}_{\text {tot }}\right)$ was determined using a modified Kjeldahl's method (Ostrowska et al., 1991), having mineralised the soil samples. The samples were mineralised in concentrated sulphuric acid, using concentrated $\mathrm{H}_{2} \mathrm{O}_{2}$ (POCh Gliwice) as a catalyst. A Büchi B-324 distillation unit (BÜCHI Labortechnik AG, Switzerland) was used for the distillation of nitrogen. The samples were titrated with $0.1 \mathrm{M} \mathrm{NaOH}$ solution against the Tashiro reagent (POCh Gliwice), using a VITLAB ${ }^{\circledR}$ continuous E/RS digital burette (VITLAB GmbH, Germany) as an indicator. Hydrolytical acidity (Hh) and the sum of basic cations (S) were determined by Kappen's method. On the basis of the above analyses, the following parameters were computed: sorption capacity (CEC) and soil base saturation (V).

\section{Statistical analysis}

The results underwent statistical processing according to the two-way analysis of variance at a level of significance of $\alpha \leq 0.05$, using the statistical calculation module of Statistica v. 10.0. The limit ranges (LSD) were determined with the two-dimensional Duncan's test. The power of the correlation between soil chemical properties, expressed by the determination coefficient $\left(R^{2}\right)$, was calculated with the aid of MS Excel 2010. The statistical significance of determination coefficients at $\mathrm{n}-2$ degrees of freedom was assessed according to tables of critical values at levels of significance of $\alpha=0.05$

Table 3. Some physicochemical properties of soil used in experiment

\begin{tabular}{|c|c|c|c|c|c|c|c|c|}
\hline \multirow{2}{*}{ Objects } & \multirow{2}{*}{$\begin{array}{l}\mathrm{pH} \\
\mathrm{KCl}\end{array}$} & $\mathrm{Hh}$ & $\mathrm{s}$ & CEC & \multirow{2}{*}{$\begin{array}{c}\mathrm{V} \\
(\%)\end{array}$} & TOC & $N_{\text {tot }}$ & \multirow{2}{*}{$\begin{array}{c}\text { TOC: } \\
\mathrm{N}_{\text {tot }}\end{array}$} \\
\hline & & \multicolumn{3}{|c|}{$\mathrm{cmol} \mathrm{kg}^{-1}$} & & \multicolumn{2}{|c|}{$\mathrm{g} \mathrm{kg}^{-1}$} & \\
\hline \multicolumn{9}{|c|}{ Experiment I (Luvisols - Albic soil) } \\
\hline without fertilization & 5.06 & 3.48 & 8.88 & 12.36 & 71.84 & 7.12 & 0.68 & 10.47 \\
\hline Slurry dose I & 5.26 & 3.59 & 10.24 & 13.83 & 74.04 & 8.78 & 0.86 & 10.21 \\
\hline Slurry dose I+PK & 5.06 & 3.35 & 10.28 & 13.63 & 75.42 & 9.81 & 0.91 & 10.78 \\
\hline Slurry dose II & 5.11 & 3.47 & 10.20 & 13.67 & 74.62 & 9.97 & 1.09 & 9.15 \\
\hline Slurry dose II+PK & 5.31 & 3.44 & 11.40 & 14.84 & 76.82 & 10.32 & 1.08 & 9.55 \\
\hline FYM & 5.46 & 3.08 & 11.60 & 14.68 & 79.02 & 11.87 & 1.21 & 9.81 \\
\hline $\mathrm{FYM}+\mathrm{PK}$ & 5.65 & 3.10 & 11.80 & 14.90 & 79.19 & 11.95 & 1.17 & 10.21 \\
\hline NPK & 4.47 & 3.96 & 9.02 & 12.98 & 69.49 & 7.98 & 0.75 & 10.64 \\
\hline \multicolumn{9}{|c|}{ Experiment II (Cambisols - Brown soil) } \\
\hline without fertilization & 4.30 & 3.35 & 4.50 & 7.85 & 57.32 & 4.44 & 0.45 & 9.87 \\
\hline Slurry dose I & 5.16 & 3.60 & 6.20 & 9.80 & 63.27 & 5.90 & 0.60 & 9.83 \\
\hline Slurry dose I+PK & 5.18 & 3.45 & 6.60 & 10.05 & 65.67 & 6.34 & 0.62 & 10.22 \\
\hline Slurry dose II & 4.34 & 3.90 & 6.00 & 9.90 & 60.61 & 7.42 & 0.69 & 10.75 \\
\hline Slurry dose II+PK & 4.50 & 4.05 & 5.60 & 9.65 & 58.03 & 7.90 & 0.67 & 11.79 \\
\hline FYM & 5.21 & 3.15 & 6.90 & 10.05 & 68.66 & 10.11 & 0.66 & 15.32 \\
\hline $\mathrm{FYM}+\mathrm{PK}$ & 5.37 & 2.95 & 6.80 & 9.75 & 69.74 & 11.12 & 0.64 & 17.38 \\
\hline NPK & 4.38 & 3.85 & 5.26 & 9.11 & 57.74 & 6.34 & 0.59 & 10.75 \\
\hline
\end{tabular}


(*) and $\alpha=0.01(* *)$, at which the determination was significant or highly significant, respectively. The frequency of the pairs of observations $(n)$ of the above determinations presented in the captions under the figures.

\section{Results and discussion}

In the light of previous studies, long-term fertilization and the application of simplified crop rotation may lead to significant changes in the composition of humic compounds. This is manifested through an increase in the content of combinations being the most movable, at the expense of the fraction being more tightly bound with the mineral portion of the soil (Ahn et al. 2009, Fangueiro et al. 2014). Presumably, a high proportion of them are compounds of the type of phenols and polyphenols which are the basic units for the synthesis of specific humic compounds. A significant proportion of these compounds exhibit high toxicity towards the plant root system and soil microorganisms (Barabasz and Vořišek 2002, Martens 2002a, $2002 b)$. The secretion of allelo-compounds by the root system is mainly limited to the rhizosphere (Bertin et al. 2003, Canals et al. 2005).

Phenolic compounds being released during both the plant vegetation and decomposition of soil organic matter contribute to a reduction in the biological activity of the soil, which may also be, to a large extent, determined by organic fertilization (Furczak et al. 2001, Barabasz and Vořišek 2002, Bielińska and Mocek 2003, Natywa et al. 2014).

The study demonstrated that the applied fertilization systems had a significant effect on the development of the content of total phenolic compounds (TPC), in relation to both grey brown podzolic soil (Luvisol - Albic Soil) and brown soil (Cambisol - Brown Soil (Fig. 3). The content of these compounds was significantly affected by both the type of soil and the type and dose of applied fertilizers. In both cases, significantly lower contents of TPC were noted in the soil from the control objects on which no fertilization was applied, as compared with the soil originating from fertilized objects. The largest accumulation of the total pool of phenols (simple phenols and polyphenols) was noted in the soil sampled from objects on which slurry was applied in dose II, equivalent to manure in terms of organic carbon being introduced into the soil. The level of these substances was 2-fold higher than that in control objects. A more intensive release of phenolic compounds from plant roots may be contributed to a low value of the solum $\mathrm{pH}$, which was reflected in the case of brown soil in relation to grey brown podzolic soil (Table 3). According to Politycka (2007), and Politycka and Seidler-Łożykowska (2009), such a situation results from the weakening of hydrogen bonds between the hydroxyl group of phenols and soil particles.

The additional enrichment of the slurry applied in dose II with mineral phosphorus and potassium resulted in a significant reduction in the TPC content in the soil from experiment II, and a slight increase, falling within the limits of statistical error, in the content of these compounds in experiment I. Slurry, similarly to manure, is an excellent source of minerals, and its fertilizer value is determined by the ratio of basic nutrients N:P:K (Sánchez and Gonzalés 2005). The introduction of this fertilizer into the soil provides it with a significant amount of organic substances, including such organic compounds as, inter alia, cellulose, lignins, hemicellulose, pentose, and starch. Fertilization with slurry results in an increase in the the content of SOM, not only in the top layer of soil, but also in deeper layers of the soil profile (Matsi 2012). Under unfavourable conditions, a low value for the ratio of TOC: $\mathrm{N}_{\text {tot }}$ (4.8-8.4:1) may result in the decomposition of soil humus and, as a consequence, may lead to both a reduction in the amount of SOM in the soil, and the emergence of undesirable organic compounds (Rochette et al. 2000, Rauber et al. 2012, Chantigny et al. 2001, Fangueiro et al. 2014). It should also be noted that the organic substance included in slurry gets into the soil with a large volume of water and, therefore, during the first period following the fertilization, the soil becomes more moist, which may affect the rate of decomposition of the organic substance and the formation of specific organic compounds. For this reason, it is necessary to monitor the effects of the application of slurry, in particular where it is applied for several years on the same field.
Luvisol Albic soil - Bałcyny

Experimient I

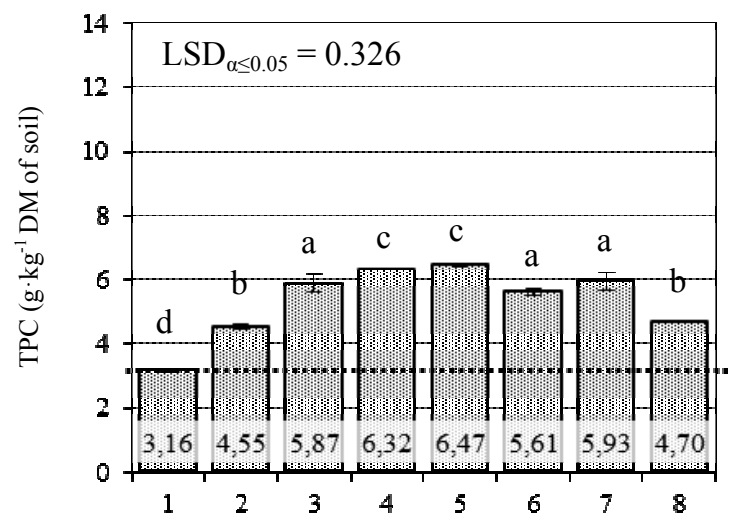

Cambisol Brown soil - Tomaszkowo Experimient II

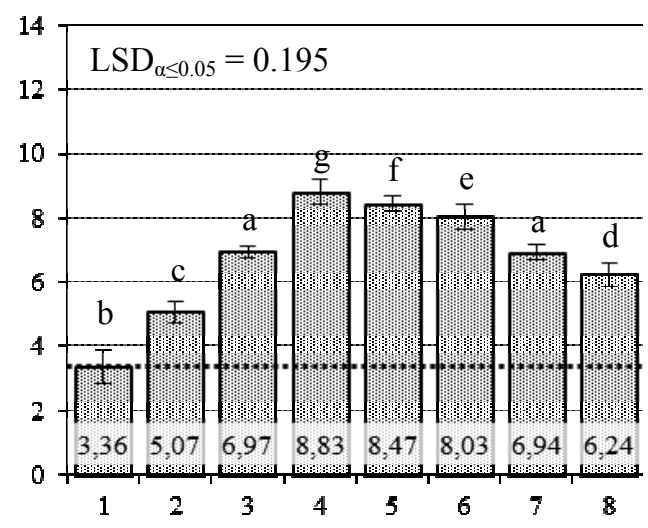

1 - without fertilization, 2 - slurry dose I, 3 - slurry dose I+PK, 4 - slurry dose II 5 - slurry dose II +PK, 6 - FYM, 7 - FYM+PK, 8 - NPK

Values given are means of three replicates \pm standard error. Different letters above the bars indicate significant differences between the treatments at $\alpha \leq 0.05$ (separately for each experiment).

Fig. 3. Effect of different fertilization systems on total phenolic compounds (TPC) content in two types of soil 
The content of TPC in both soils fertilised with manure significantly increased compared with the content of these compounds in the soil from other objects onto which nitrogen was introduced at the same amount as in manure (slurry at dose I, NPK). Phenolic compounds found in manure may originate from various sources; these are, inter alia, phenols dissolved in cell saps of the feed, included in cell walls of the plants used as bedding for livestock, and phenols released as a result of microbial activity in animals' stomachs during lignin decomposition. Their presence is also found during manure composting (Jung et al. 1983).

As reported by Gallet et al. (2003), the content of phenolic compounds in the leachate originating from soils fertilized with manure, similarly to all water soluble components, is, to a large extent, dependent on the course of weather conditions, in particular the amount of precipitation. During the first five weeks following the application of manure in the authors' study, the concentration of total phenols and syringic acid in the soil leachate only changed slightly, while after the first rainfall the concentration of these compounds increased significantly. It is therefore very likely that after the application of manure in the field the first rainfall will release considerable amounts of substances being potentially harmful to certain organisms. An example may be syringic acid, which becomes a germination inhibitor if occurring at a concentration of $5 \cdot 10^{-4} \mathrm{M} \cdot \mathrm{dm}^{-3}$, or a growth inhibitor if occurring at a concentration of $10^{-5} \mathrm{M} \cdot \mathrm{dm}^{-3}$. Organic fertilization may pose a hazard to water as the concentration of certain compounds in the leachate originating from soils fertilized with these fertilizers considerably exceeds the maximum permissible values for drinking water. The rate of their spread in the soil seems high enough to possibly cause the hazard of water contamination in the event of heavy rainfall, particularly after periods of drought (Gallet et al. 2003, Sądej and Przekwas 2006a, 2006b).

The enrichment of slurry dose I with mineral phosphorus and potassium resulted in a significant increase in TPC in both grey brown podzolic and brown soil, as compared to the fertilization with organic fertilizers only. A similar relationship was found for manure fertilization with additional PK fertilization, yet only for grey brown podzolic soil.

Phenolic compounds, in particular their water-soluble forms (Gallet and Keller 1999), similarly to mineral compounds
(Sądej and Przekwas 2006a, 2006b), when migrating to deeper layers of soil, may pose an environmental hazard, since in the event of having penetrated into the groundwater they affect the concentration of these compounds in sources of drinking water. It has been reported that contamination of drinking water with phenolic substances leaching downward into the soil profile is a frequent problem for intakes, water from which is treated using chlorine. Harmful haloforms (trihalogenomethanes) are then formed, and phenolic acids are transformed into chlorophenols whose toxicity is comparable to that of the Escherichia coli strain inhabiting human intestines (Vlková and Církva 2005).

The content of water-soluble phenolic compounds (WSPC) in both soils was significantly dependent on the fertilization system applied, whereas grey brown podzolic soil was characterised by the WSPC content being higher by an average of $31.6 \%$ than that of brown soil (Table 4 ). In both experiments, fertilization with manure contributed to a significant increase in the content of water-soluble fractions of phenolic compounds in relation to the content noted in control objects. This increase amounted to $0.16 \mathrm{~g} \mathrm{WSPC}$ in brown soil, and to $0.38 \mathrm{~g} \mathrm{WSPC} \cdot \mathrm{kg}^{-1} \mathrm{DM}$ in grey brown podzolic soil, respectively. A very large (over 30 -fold) increase in the concentration of water-soluble phenolic compounds under the influence of fertilization with manure was obtained in a study by Gallet et al. (2003). Slurry applied in dose I, being equivalent to a dose of manure in terms of the introduced nitrogen, had a similar action to that of manure. As regards brown soil, such an effect of action was also found for slurry applied in dose II, being equivalent to manure in terms of the introduced organic carbon. In grey brown podzolic soil this fertilization method contributed to the largest increase in the WSPC content of all the fertilization objects. Supplementary PK fertilization applied along with natural fertilizers resulted in a further increase in the WSPC content as compared with the objects fertilized solely with natural fertilizers, whereas for grey brown podzolic soil this increase was only significant in the object where slurry was applied in dose I + PK. In experiment II carried out on brown soil the WSPC content in the soil fertilized solely with mineral fertilizers was higher by $15.8-20.4 \%$ than the soil fertilized with natural fertilizers

Table 4. Effect of different fertilization systems on WSPC concentration in two types of soil

\begin{tabular}{|c|c|c|c|c|c|c|c|c|}
\hline & \multicolumn{4}{|c|}{ Luvisol Albic soil - Bałcyny } & \multicolumn{4}{|c|}{ Cambisol Brown soil - Tomaszkowo } \\
\hline Objects & \multicolumn{2}{|c|}{ WSPC } & \multicolumn{2}{|c|}{$\begin{array}{c}\% \text { share } \\
\text { of WSPC in TPC }\end{array}$} & \multicolumn{2}{|c|}{ WSPC } & \multicolumn{2}{|c|}{$\begin{array}{c}\% \text { share } \\
\text { of WSPC in TPC }\end{array}$} \\
\hline Without fertilization & $1.03^{d}$ & \pm 0.02 & $32.59^{a}$ & \pm 0.37 & $0.91^{\mathrm{e}}$ & \pm 0.02 & $27.08^{e}$ & \pm 0.52 \\
\hline Slurry dose I & $1.32^{\mathrm{a}}$ & \pm 0.03 & $29.01^{c}$ & \pm 0.59 & $1.03^{a}$ & \pm 0.02 & $20.31^{a}$ & \pm 0.32 \\
\hline Slurry dose I+PK & $1.55^{b}$ & \pm 0.02 & $26.44^{\mathrm{b}}$ & \pm 0.45 & $1.41^{d}$ & \pm 0.01 & $20.23^{a}$ & \pm 0.18 \\
\hline Slurry dose II & $2.00^{c}$ & \pm 0.05 & $31.65^{\mathrm{ac}}$ & \pm 0.75 & $1.04^{\mathrm{a}}$ & \pm 0.03 & $11.78^{b}$ & \pm 0.37 \\
\hline Slurry dose II+PK & $2.02^{c}$ & \pm 0.02 & $31.22^{a c}$ & \pm 0.24 & $1.29 \mathrm{bc}$ & \pm 0.03 & $15.22^{d}$ & \pm 0.25 \\
\hline FYM & $1.41^{\mathrm{a}}$ & \pm 0.02 & $25.14^{\mathrm{b}}$ & \pm 0.47 & $1.07^{a}$ & \pm 0.02 & $13.33^{c}$ & \pm 0.40 \\
\hline FYM+PK & $1.42^{a}$ & \pm 0.02 & $24.04^{b}$ & \pm 1.05 & $1.36^{\mathrm{cd}}$ & \pm 0.01 & $19.60^{a}$ & \pm 0.23 \\
\hline NPK & $1.55^{b}$ & \pm 0.03 & $32.99^{a}$ & \pm 0.78 & $1.24^{b}$ & \pm 0.02 & $19.87^{a}$ & \pm 0.40 \\
\hline Mean: & \multicolumn{2}{|c|}{1.54} & \multicolumn{2}{|c|}{29.13} & \multicolumn{2}{|c|}{1.17} & \multicolumn{2}{|c|}{18.43} \\
\hline $\operatorname{LSD}_{\alpha \leq 0.05}$ & \multicolumn{2}{|c|}{0.101} & \multicolumn{2}{|c|}{2.338} & \multicolumn{2}{|c|}{0.086} & \multicolumn{2}{|c|}{1.289} \\
\hline
\end{tabular}


applied in doses being equivalent in terms of the introduced nitrogen (manure, slurry in dose I). In grey brown podzolic soil these differences amounted to $9.9 \%$ (manure) and $17.4 \%$ (slurry at dose I), respectively.

The percentage of water-soluble phenolic compounds in the total content thereof in grey brown podzolic soil ranged from 24.04 to $32.99 \%$, and in brown soil it ranged from 11.78 to $27.08 \%$ (Table 4). In experiment I the highest percentage thereof was found in the soil originating from the control object and from the objects fertilized with mineral fertilizers and slurry in dose II, while in experiment II, in the soil originating from the control object. In both experiments fertilization with manure resulted in a reduction in the percentage of water- soluble phenolic compounds in the total content thereof as compared with other objects being equivalent in terms of the introduced nitrogen (objects fertilized with slurry in dose I and NPK).

Statistical analysis indicates that the content of phenolic compounds in the soils was significantly correlated with the contents of TOC and $\mathrm{N}_{\text {tot }}$ (Figs 4 and 5). Regression analysis results indicate that the maximum accumulation of TPC occurred in the TOC content at a level of $10.76 \mathrm{~g} \mathrm{C} \cdot \mathrm{kg}^{-1} \mathrm{DM}$ for grey brown podzolic soil, and $8.83 \mathrm{~g} \mathrm{C} \cdot \mathrm{kg}^{-1} \mathrm{DM}$ for brown soil, while the maximum accumulation of WSPC, respectively for the soils under analysis, occurred in the TOC content at a level of 10.03

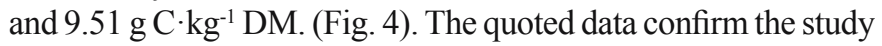
results obtained by Rimmer and Abbott (2011), who demonstrated that an increase in the contents of phenolic compounds in various soils occurred along with an increase in the SOM content therein. Their content was also dependent on both the land use regime and the type of plant residues. According to Rimmer (2006), phenolic compounds may be an important factor determining the antioxidant capacity (AOC) of soil extracts. The author demonstrated a statistically significant relationship between the
AOC of extracts and total phenolic compounds. In the quoted study both these variables were also positively correlated with the content of organic matter in the soil.

Significant relationships were also demonstrated between the contents of TPC, WSPC and the content of $\mathrm{N}_{\text {tot }}$ (Fig. 5). The obtained significant $R^{2}$ coefficients suggest that the maximum contents of TPC and WSPC in grey brown podzolic soil are found in the content of $\mathrm{N}_{\text {tot }}$ at a level ranging from 1.05 to $1.11 \mathrm{~g} \mathrm{~N} \cdot \mathrm{kg}^{-1} \mathrm{DM}$ soil. As regards brown soil, it was demonstrated that the content of TPC increased successively with the increase in the content of $\mathrm{N}_{\text {tot }}$, while the maximum accumulation of the WSPC occurred with the content of $\mathrm{N}_{\text {tot }}$ being at a level of $0.64 \mathrm{~g} \mathrm{~N} \cdot \mathrm{kg}^{-1} \mathrm{DM}$ of soil. A high $R^{2}$ coefficient also indicates a significant relationship between TPC and C:N ratio in relation to brown soil (Fig. 6). Such relationships were not demonstrated for TPC in grey brown podzolic soil or the WSPC content in both types of soil.

\section{Conclusions}

1. A significant influence was found of multiannual fertilization on the content of total phenolic compounds and their water-soluble forms in brown and grey brown podzolic soils. Each fertilization system resulted in an increase in the content of both forms of the analysed compounds in relation to control objects. Brown soil was characterised by an average content of total phenolic compounds, being higher than grey brown podzolic soil. In turn, the content of water-soluble phenolic forms in these soils was opposite.

2. In both soils, the highest content of total phenolic compounds was found in the soil from objects fertilized with slurry applied at a dose being equivalent to manure in terms of the amount of introduced organic carbon.
Luvisol Albic soil - Bałcyny
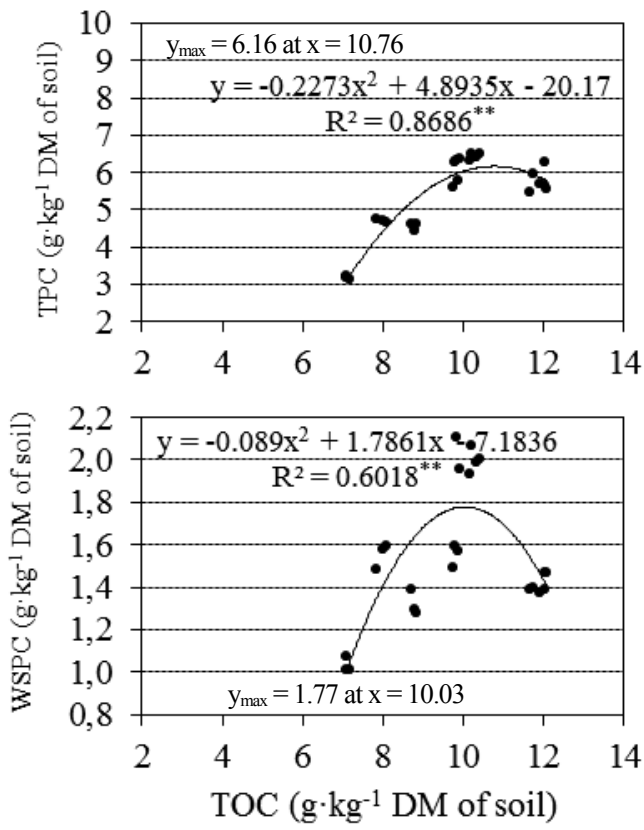

\section{Cambisol Brown soil - Tomaszkowo}
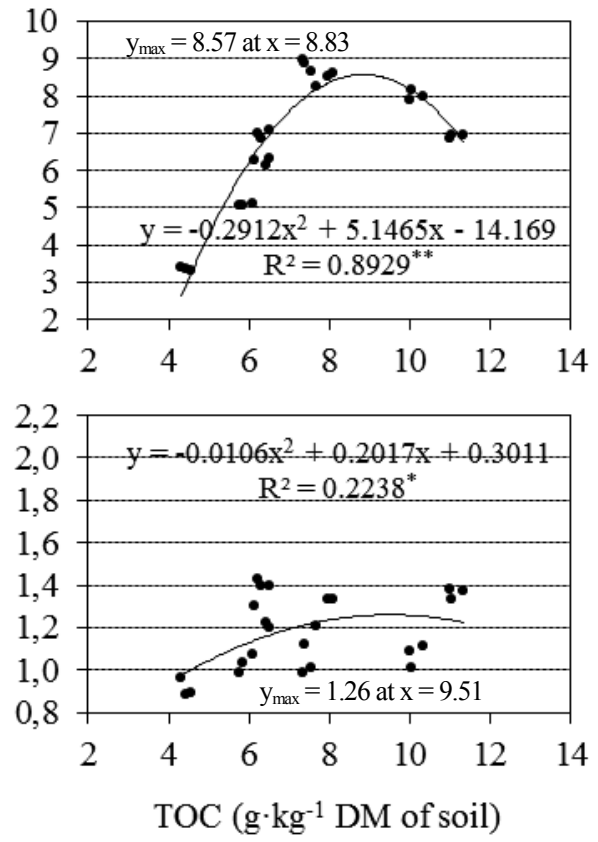

$*-R^{2}$ coefficient significant at $\alpha \leq 0.05, * *-R^{2}$ coefficient significant at $\alpha \leq 0.01$, n.s. $-R^{2}$ coefficient non-significant, $\mathrm{n}=24$.

Fig. 4. Relationships between organic $C$ (TOC) content and TPC and WSPC in two types of soils 
3. Supplementary mineral fertilization with PK, applied along with organic fertilizers, particularly in brown soil, significantly elevated the content of water-soluble phenolic compounds. In grey brown podzolic soils, this impact was only visible in the object fertilized with slurry at a dose being equivalent to manure in terms of the amount of introduced total nitrogen.

Luvisol Albic soil - Bałcyny
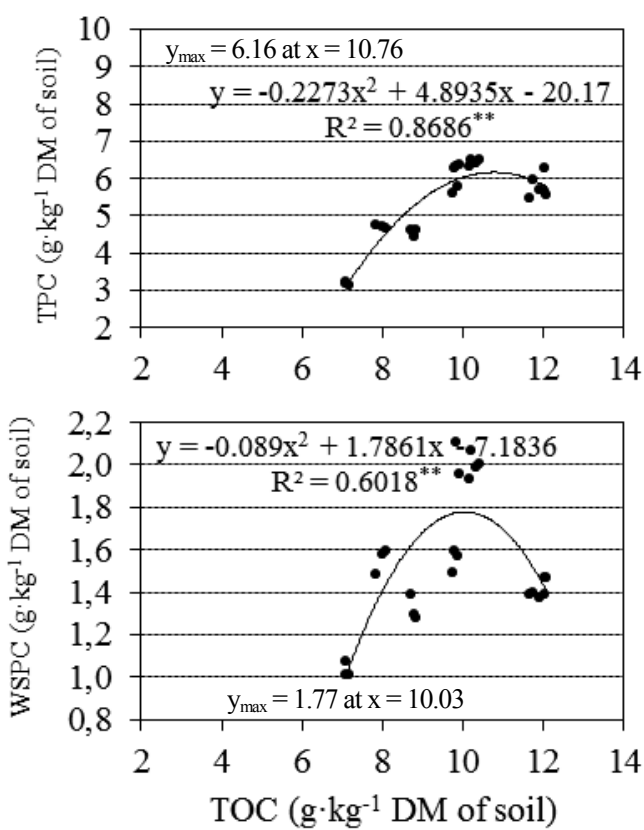

4. The percentage of water-soluble forms of phenols in the total content of these compounds in grey brown podzolic soil was at a level of $18.4 \%$, while in brown soil it amounted to $29.1 \%$.

5. The content of total phenolic compounds and their water-soluble forms was closely linked to the contents of organic carbon and total nitrogen in the soil. High determination coefficients $R^{2}$ indicate a significant correlation power.

Cambisol Brown soil - Tomaszkowo
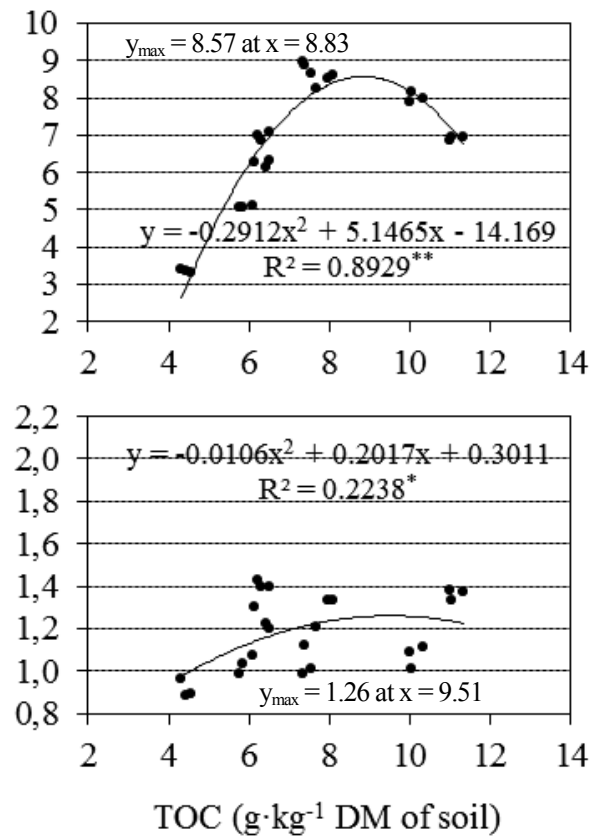

$*-R^{2}$ coefficient significant at $\alpha \leq 0.05, * *-R^{2}$ coefficient significant at $\alpha \leq 0.01$, n.s. $-R^{2}$ coefficient non-significant, $\mathrm{n}=24$.

Fig. 5. Relationships between Ntot content and TPC and WSPC in two types of soils

Luvisol Albic soil - Bałcyny
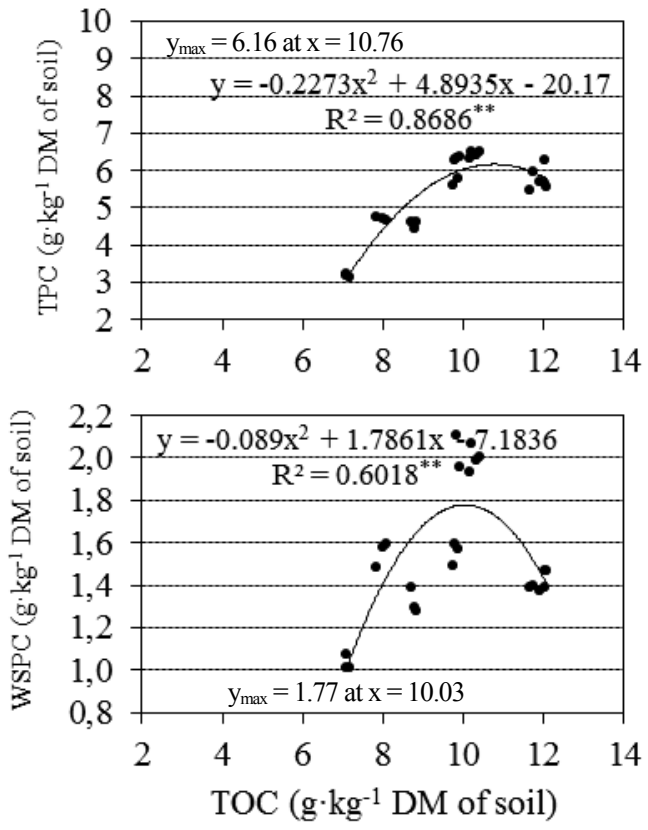

Cambisol Brown soil - Tomaszkowo
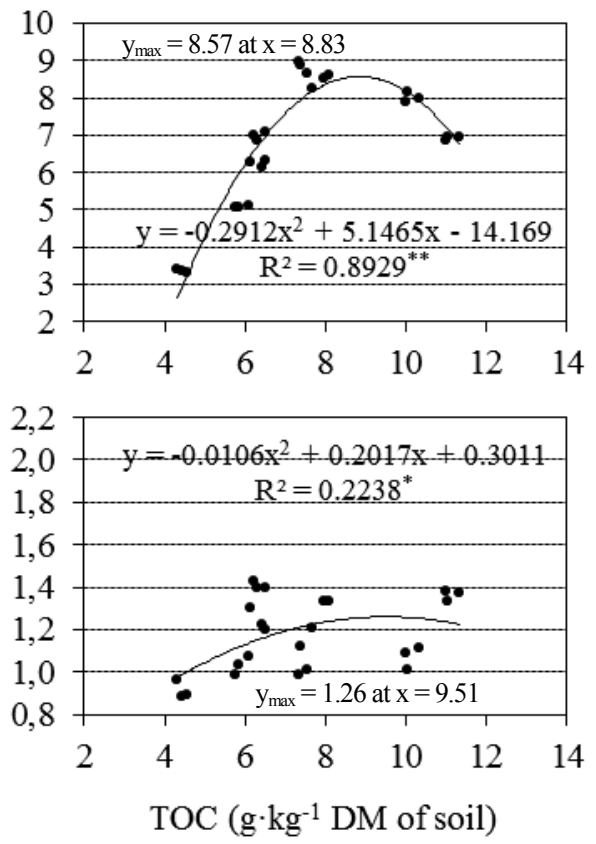

$*-R^{2}$ coefficient significant at $\alpha \leq 0.05, * *-R^{2}$ coefficient significant at $\alpha \leq 0.01$, n.s. $-R^{2}$ coefficient non-significant, $\mathrm{n}=24$.

Fig. 6. Relationships between C:N ratio and TPC and WSPC in two types of soils 


\section{Acknowledgement}

This study was developed based on a field experiment, the originator of which was Professor Teofil Mazur, PhD. In the paper, the results of studies financed from the resources of Statutory Grant of the UWM in Olsztyn No. 528.1004.0805 were used.

\section{References}

Ahmad, N. \& Bano, A. (2013). Impact of allelopathic potential of maize (Zea mays L.) on physiology and growth of soybean [Glycine max (L.) Merr.], Pakistan Journal of Botany, 45(4), pp. 1187-1192.

Ahn, M., Zimmerman, A.R., Comerford, N.B., Sickman, J.O. \& Grunwald, S. (2009). Carbon mineralization and labile organic carbon pools in the sandy soils of a north Florida watershed, Ecosystems, 12, pp. 672-685.

Aoyama, M. \& Kumakura, N. (2001). Quantitative and qualitative changes of organic matter in an Ando soil induced by mineral fertilizer and cattle manure applications for 20 years, Soil Science and Plant Nutrition, 47, pp. 241-252.

Barabasz, W. \& Vořišek, K. (2002). The biodiversity of microorganisms in soil environments, in: The activity of microorganisms in different environments, Barabasz W. (Ed.), Kraków, AR, pp. 23-34. (in Polish)

Bertholdsson, N.O. (2004). Variation in allelopathic activity over one hundred years of barley selection and breeding, Weed Research, 44, pp. 78-86.

Bertin, C., Yang, X. \& Weston, L.A. (2003). The role of root exudates and allelochemicals in the rhizosphere, Plant and Soil, 256, pp. 67-83.

Bielińska, E.J. \& Mocek, A. (2003). Enzymatic activity of soil under orchard as an indicator of environmental condition brought about by use of plastics for soil mulch, Zeszyty Problemowe Postępów Nauk Rolniczych, 492, pp. 25-37. (in Polish)

Bonanomi, G., Incerti, G., Antignani, V., Capodilupo, M. \& Mazzoleni, S. (2010). Decomposition and nutrient dynamics in mixed litter of Mediterranean species, Plant Soil, 331, pp. 481-496.

Bouhaouel, I., Gfeller, A., Fauconnier, M.-L., Rezgui, S., Amara, H.S. \& Jardin, P. (2015). Allelopathic and autotoxicity effects of barley (Hordeum vulgare L. ssp. vulgare) root exudates, BioControl, 60, pp. $425-436$.

Canals, R.M., Emeterio, L.S. \& Peralta, J. (2005). Autotoxicity in Lolium rigidum: analyzing the role of chemically mediated interactions in annual plant populations, Journal of Theoretical Biology, 235, pp. 402-407.

Chantigny, M.H., Rochette, P. \& Angers, D.A. (2001). Short-term C and $\mathrm{N}$ dynamics in a soil amended with pig slurry and barley straw: a field experiment, Canadian Journal of Soil Science, 81, pp. 131-137.

Djurdjević, L., Dinić, A., Pavlović, P., Mitrović, M., Karadžić, B. \& Tešević, V. (2004). Allelopathic potential of Allium ursinum L., Biochemical Systematics and Ecology, 32, pp. 533-544.

Djurdjević, L., Gajić, C., Kostić, O., Jarić, S., Pavlović, C., Mitrović, M. \& Pavlović, P. (2012). Seasonal dynamics of allelopathically significant phenolic compounds in globally successful invader Conyza canadensis L. plants and associated sandy soil, Flora, 207, pp. 812-820.

Epstein, E., Taylor, J.M. \& Chaney, R.L. (1976). Effects of sewage sludge and sludge compost applied to soil on some soil physical and chemical properties, Journal of Environmental Quality, 5, pp. 422-426.

Fangueiro, D., Coutinho, J., Borges, L., F. Cabral, F. \& Vasconcelos, E. (2014). Nitrogen and carbon availability of liquid and solid fractions of pig slurry obtained using different separation technologies, Biology and Fertility of Soils, 50, pp. 333-341.
Furczak, J., Deryło, S. \& Szymankiewicz, K. (2001). Microbial activity and content of phenolic compounds in podzolic soil under winter rye cultivated in different systems, Zeszyty Problemowe Postępów Nauk Rolniczych, 478, pp. 135-144.

Gallet, C. \& Keller, C. (1999). Phenolic composition of soil solutions: comparative study of lysimeter and centrifuge waters, Soil Biology and Biochemistry, 31, pp. 1151-1160.

Gallet, Ch., Boissier, J-M. \& Berlandis, M. (2003). Short-term effects of manure application on soil leachates in a mountain catchment, Agronomie, 23, pp. 335-344.

Gartner, T.B. \& Cardon, Z.G. (2004). Decomposition dynamics in mixed-species leaf litter, Oikos, 104 (2), pp. 230-246.

Hanya, T., Matsumoto, G., Nagao, T. \& Katase, T. (1976). The presence of $\mathrm{p}$-coumaric and ferulic acids in natural waters and their significance in relation to environmental health, Trace Substances and Environmental Health, 10, pp. 265-269.

Haynes, R.J. \& Naidu, R. (1998). Influence of lime, fertilizer and manure applications on soil organic matter content and soil physical conditions: a review, Nutrient Cycling in Agroecosystems, 51, pp. 123-137.

Hruszka, M. (1982a). Autotoxicity of wheat and field beans grown in monoculture. 1. Pot experiments, Zeszyty Naukowe Akademii Rolniczo-Technicznej w Olsztynie, 32, pp. 91-99. (in Polish)

Hruszka, M. (1982b). Autotoxicity of wheat and field beans grown in monoculture. 2. Laboratory studies, Zeszyty Naukowe Akademii Rolniczo-Technicznej w Olsztynie, 32, pp. 101-107. (in Polish)

IUSS Working Group WRB. 2014. World Reference Base for Soil Resources. International soil classification system for naming soils and creating legends for soil maps, World Soil Resources Reports No. 106. FAO. Rome. www.fao.org/3/a-i3794e.pdf

Jung, H.G.G., Fahey, G.C. \& Merchen, N.R. (1983). Effects of ruminant digestion and metabolism on phenolic monomers of forages. British Journal of Nutrition, 50, pp. 637-651.

Krupa, T. \& Latocha, P. (2007). Antioxidant activity and contents of vitamin $\mathrm{C}$ and phenolic compounds in fruit of various hardy kiwifruit (Actinidia Lindl.) genotypes, Żywność - Nauka Technologia Jakość 5, pp. 237-244. (in Polish)

Li, Z.H., Wang, Q., Ruan, X., Pan, C.D. \& Jiang, D.A. (2010). Phenolics and plant allelopath, Molecules, 15, pp. 8933-8952.

Lowe, L.E. (1993). Total and labile polysacharide analysis of soils, in: Soil sampling and methods of analysis, Carter, M.D. (Ed.), Canadian Society of Soil Science, Lewis Publishers: pp. 373-376.

Malá, J., Cvikrová, M., Hrubcová, M. \& Máchová, P. (2013). Influence of vegetation on phenolic acid contents in soil, Journal of Forest Science, 59(7), pp. 288-294.

Martens, D.A. (2002a). Identification of phenolic acid composition of alkali-extracted plants and soils, Soil Science Society of America Journal, 66, pp. 1240-1248.

Martens, D.A. (2002b). Relationship between plant phenolic acids released during soil mineralization and aggregate stabilization, Soil Science Society of America Journal, 66, pp. 1857-1867.

Matsi, T. (2012). Liquid cattle manure application to soil and its effect on crop growth, in: Soil fertility improvement and integrated nutrient management - a global perspective, Whalen, J.K. (Ed.), InTech Europe, pp. 97-118.

Mazzoleni, S., Bonanomi, G., Giannino, F., Rietkerk, M., Dekker, S.C. \& Zucconi, F. (2007). Is plant biodiversity driven by decomposition processes? An emerging new theory on plant diversity, Community Ecology, 8(1), pp. 103-109.

Natywa, M., Selwet, M. \& Maciejewski, T. (2014). Effect of some agrotechnical factors on the number and activity soil microorganisms, Fragmenta Agronomica, 31(2), pp. 56-63. (in Polish)

Northrup, R.R., Dahlgren, R.A., Aide, T.M. \& Zimmerman, J.K. (1999). Effect of plant polyphenols on nutrient cycling and implications for community structure, in: Inderjit, Dakshini, K.M.M., Foy, C.L. 
(Eds.), Principles and Practices in Plant Ecology, CRC Press, pp. 369-380.

Ostrowska, A., Gawliński, S. \& Szczubiałka, Z. (1991). Methods of analysis and assessment of soil and plant properties, Institute of Environmental Protection, pp. 333. (in Polish)

Paul, J.W., Covert, J.A. \& Beauchamp, E.G. (1993). Influence of soil temperature and moisture on water-soluble compounds in manured soil, Canadian Journal of Soil Science, 74, pp. 111-114.

Politycka, B. (2007). Substrate reaction and phytotoxicity of root residues of apple trees, Nauka Przyroda Technologie, 1(1), pp. 1-6. (in Polish)

Politycka, B. \& Seidler-Łożykowska, K. (2009). Phytotoxicity and phenolic compounds content in soil during long-term cultivation of lemon balm (Melissa officinalis L.) and its effect on herb yield essential oil content, Herba Polonica, 55(3), pp. 133-139.

Rauber, L.P., Piccolla, C.D., Andrade, A.P., Friederichs, A., Mafra, A.L., Corrêa, J.C. \& Albuquerque, J.A. (2012). Physical properties and organic carbon content of a Rhodic Kandiudox fertilized with pig slurry and poultry litter, Revista Brasileira de Ciência do Solo, 36, pp. 1323-1332.

Reigosa, M.J. \& Pedrol, N. (2002). Allelopathy: from molecules to ecosystems, Science Publishers, Enfield. NH, pp. 316.

Riffaldi, R., Saviozzi, A. \& Levi-Minzi, R. (1988). Water extracts of fresh and mature farmyard manure, Biological Wastes, 23, pp. 65-72.

Rimmer, D.L. (2006). Free radicals, antioxidants, and soil organic matter recalcitrance, European Journal of Soil Science, 57, pp. 91-94.

Rimmer, D.L. \& Abbott, G.D. (2011). Phenolic compounds in $\mathrm{NaOH}$ extracts of UK soils and their contribution to antioxidant capacity, European Journal of Soil Science, 62, pp. 285-294.

Rochette, P., Angers, D.A. \& Côté, D. (2000). Soil carbon and nitrogen dynamics following application of pig slurry for the 19th consecutive year: I. Carbon dioxide fluxes and microbial biomass carbon, Soil Science Society of America Journal, 64, pp. $1389-1395$.

Sánchez, M. \& González, J.L. (2005). The fertilizer value of pig slurry. I. Values depending on the type of operation, Bioresource Technology, 96 (10), pp. 1117-1123.
Sądej, W. \& Przekwas, K. (2006a). Effects of point pollution sources on nitrogen concentrations in surface waters, Polish Journal of Environmental Studies, 15, 5d, Part II: pp. 401-404.

Sądej, W. \& Przekwas, K. (2006b). Effect of point pollution sources on nitrogen concentrations in well water, Zeszyty Problemowe Postępów Nauk Rolniczych, 513: pp. 365-372.

Sołtys, D., Dębska, K., Bogatek, R. \& Gniazdowska, A. (2010). Plant autotoxicity - an example of allelopathic interaction, Kosmos, 59(3-4), pp. 551-565. (in Polish)

Szwed, A. \& Bohacz, J. (2014). Enzymatic activity and certain chemical properties of grey-brown podzolic soil (Haplic Luvisol) amended with compost of tobacco wastes, Archives of Environmental Protection, 40, 3, pp. 61-73.

Thakur, Ch., Deo Mall, I. \& Srivastava, V.C. (2013). Effect of hydraulic retention time and filling time on simultaneous biodegradation of phenol, resorcinol and catechol in a sequencing batch reactor, Archives of Environmental Protection, 39, 2, pp. 69-80.

Tiessen, H. \& Moir, J.O. (1993). Total and organic carbon, in: Soil sampling and methods of analysis, Carter, M.R. (Ed.), Canadian Society of Soil Science, Lewis Publishers: pp. 187-199.

Vlková, L. \& Církva, V. (2005). Chlorinated phenols and methods of their degradation, Chemické Listy, 99, pp. 125-130. (in Czech)

Wang, K., Cai, J., Xie, S., Jia Feng, J. \& Wang, T. (2015). Phytoremediation of phenol using Polygonum orientale and its antioxidative response, Archives of Environmental Protection, 41,3, pp. 39-46.

Wardle, D.A., Nilsson, M.C., Zackrisson, O. \& Gallet, C. (2003). Determinants of litter mixing effects in a Swedish boreal forest, Soil biology and biochemistry, 35, pp. 827-835.

Wise, A.A. \& Kuske, C.R. (2000). Generation of novel bacterial regulatory proteins that detect priority pollutant phenols, Applied Environmental Microbiology, 60(1), pp. 163-169.

Wójcik-Wojtkowiak, D., Politycka, B. \& Weyman-Kaczmarkowa, W. (1998). Allelopathy, AR Poznań, pp. 90. (in Polish)

Wu, H., An, M., Liu, D.L., Pratley, J. \& Lemerle, D. (2008). Recent advances in wheat allelopathy, in: Allelopathy in Sustainable Agriculture and Forestry, Zeng, R.S., Mallik, A.U., Luo, S.M.(Eds.), Springer Science+Business Media, LLC, pp. 235-254.

\title{
Zawartość związków fenolowych w glebach pochodzących $z$ dwóch trwałych doświadczeń nawozowych
}

\begin{abstract}
Strzeszczenie: Związki fenolowe to grupa substancji biologicznie aktywnych, pochodząca najczęściej z naturalnych przemian substancji organicznej bądź z biosyntezy prowadzonej przez mikroorganizmy. Istota działania tych związków w glebie polega na zaburzaniu przemian metabolicznych w roślinie, co powoduje zahamowanie ich wzrostu i obniżenie plonowania. Celem pracy było porównanie wpływu trzech systemów wieloletniego nawożenia stosowanego w dwóch trwałych doświadczeniach polowych na zawartość związków fenolowych w glebie. W badaniach stosowano nawozy naturalne (obornik, gnojowica), mineralne (NPK) oraz nawożenie łączne organiczno-mineralne. Doświadczenie I założono w 1972 r. na glebie płowej, natomiast doświadczenie II w 1973 r. na glebie brunatnej. W obu doświadczeniach rośliny uprawiano w 7-letnim zmianowaniu, z 75\% udziałem zbóż. Materiał do badań stanowily próbki pobrane z wierzchniej warstwy gleby po 36 (doświadczenie I) i 35 (doświadczenie II) latach od chwili założenia doświadczeń. Wykazano, że obecność związków fenolowych w glebach była istotnie uzależniona od zawartości C organicznego oraz $\mathrm{N}$ ogółem. Na ich zawartość istotny wpływ miał rodzaj gleby oraz rodzaj i dawka stosowanych nawozów. W glebie płowej średnia zawartość związków fenolowych ogółem kształtowała się na poziomie niższym w stosunku do zawartości stwierdzanych w glebie brunatnej. Wieloletnie nawożenie wpłynęło na wzrost zawartości związków fenolowych ogółem w stosunku do wartości uzyskanych w obiektach kontrolnych, co szczególnie uwidoczniło się w glebie pochodzącej z obiektów nawożonych gnojowicą, stosowaną $\mathrm{w}$ dawce równoważonej $\mathrm{z}$ obornikiem pod względem ilości wprowadzanego węgla organicznego. Udział form fenoli rozpuszczalnych w wodzie w ogólnej zawartości tych związków w glebie płowej kształtował się średnio na poziomie $18.4 \%$, zaś w glebie brunatnej $29.1 \%$.
\end{abstract}

